\title{
The Impact of Economical Transition in Human Resources Development in Kosovo Enterprises
}

\section{Msc. Ariana Xhemajli PhD(c)}

University "Haxhi Zeka" Peje Kosovo

\author{
MA. Alma Shehu Lokaj PhD (c) \\ University "Haxhi Zeka" Peje/Kosovo
}

Doi:10.5901/ajis.2015.v4n1s1p41

\section{Abstract}

During the globalization process, countries in transition have faced with different challenges in terms of adaptation in an open economy and as well as in the preparation of human resources to overpass such challenges. The innovations that brought the open economy like foreign direct investments, bringing of new technologies, new management methods, etc, have cause also problems like those in privatization process and in the management of human resources, in order to create the necessary capacities and create competitive advantages in a dynamic market. Kosovo, as one of newest countries in the world, with a centralized economy until 1999, is facing many challenges to successfully pass the long and troublesome process. The companies in Kosovo even after so many years has not find the right solution to be competitive in local and international market and one of the disadvantages is the importance that these companies give to their human resources. Another challenge is the reform in education. The new economy brings challenges that should be faced by knowledge people and this is achievable with the right and appropriate education for Kosovo market. The transition economy in Kosovo requires maximal efforts from the central government and entrepreneurs to succeed in the local and international market challenges. In this paper we will try to give some recommendations for human resources managers in Kosovo and the way they should follow to improve their skills in managing the people and face the challenges of their companies. The preparation of the new working force is depended, in a big part, from the universities and this paper will deal also with some issues regarding the problems presented in the university's program on human resources management. The methodology is based on qualitative and comparative secondary dates and a critical analysis has been done to highlight the problems in developing human resources in Kosovo. The reason why is chosen this methodology is to compare the developing of HR in Kosovo with other in transition countries.

Keywords: transition, globalization, human resources management, education

\section{Introduction}

In transition economies or in transformation economies are those changing from a centralized to an open economy. After this process of economic freedom the countries previously centralized, especially Kosova, started to make the first steps toward the new economy very often without taking into consideration the difficulties.

According to Svetlik (2010) generally speaking, HRM activity in most East European countries, including the countries of the former Yugoslavia - prior to the changes that took place at the end of the 1980s, was very tightly controlled by the state. Personnel (meaning management-) related issues were under the close control of the party and of heads of state, whilst the key positions in companies were closely monitored by the party and by the state bureaucracy.

The institutions of Kosova started to establish the legislation and the right infrastructure trying to give the right direction to country's economic activities. Although the legislation and the infrastructure, even after 15 years, Kosova is not achieving the expected results. Is a part of the fault to government policies? This is a question to which we find the answer why some in transition countries are developed and succeeded in this process and some other are not. If we can call it "the economic revolution" in Kosova has made that many privatized companies and the new established think about the development of their businesses in way to create profit. One of the key points of these companies are the human resources. The companies started to be aware of the importance of human resources and that without these well prepared resources the companies can't achieve the their objectives.

Human resources management in Kosovo companies is presented as a very complicated process because of:

- Lack of preparing the managers to respond to the transition changes; 
- Domination of bureaucracy and administrative issues in managing the company;

- $\quad$ Frequent changes in managerial staff;

- $\quad$ Lack of experience in managing;

- Change of ownership

- Problems of recruiting the right staff

These are only some of the problems facing the companies in Kosovo for managing the human resources during this transition period.

\section{Academic Debates}

Haslinda (2009) states that human resources are an organization's greatest assets because without them, everyday business functions such as managing cash flow, making business transactions, communicating through all forms of media, and dealing with customers could not be completed.

According to Bool and Hooijberg (2001) effective leaders are essential to good human resources management system. Effective leaders articulate the need for sound HR practices and skillfully sail through organizational process for these practices to develop and sustain. For Law, Tse and Zhow (2002) this is especially salient to firm management in transitional economies where uncertainties and risks would imply business failure and massive layoffs.

Ahmeti (2014) state that what and still is the most crucial change that needs to happen is that individuals had to familiarize themselves to a new, rather different reality economic environment, compared to the former socialist state where that state was the warrant and planner for every economic action.

Gary Dessler $(2009,2)$ defined that human resource management refers to the practices and policies that managers need to carry out the personnel aspects of the management job which includes acquiring, training, appraising, rewarding. Besides, managers need to provide a working environment with safety, ethic and fairness for the company's employees.

According to Thi Hoe (2013) as well as the rapid change in the organization system and other external factors (economic, technology), the managing human resource also changes to be able to adapt to the new trends and compete to other competitors.

This evolution in education patterns should continue towards the transition from the coal- to the knowledge-based economy and society (see Kukliński, 2001).

One of the important pillars of the knowledge-based economy is human capital. This may be enhanced by education, which nowadays is an important element of socio-economic life and a key factor for success.

A particular justification according to Garavan, Heraty \& Barnicle, (1999) for HRD posited within the literature relates to competitive advantage. It is argued that sustainable competitive advantage can be achieved through continuous investment in HRD at the level of the individual firm.

\section{Transition and Human Resources in Kosova}

According to a report of RIINVES (Institute for Development Researches) the economic growth process is followed by wide spectrum of policies: development financing, public infrustructure, regulatory framework, industrial policies, government intervenation. The serious reforms oriented toward the construction of the economy based to the market and the creation of the economic stabilisation and policies which are the key factors for the economic growth in economis in transition. The challange of countries in development, as an economy involved by the globalization and growth, must be focused in exceeding the problems in these fildes:

- Savings, respectively inadequate investments

- Inadequate workforce

- The worsening of conditions for trade

- Weak institutions

In this report inadequate workforce is listed the second and as one of many problems in developing and the performance of businesses in Kosovo and for its economy in general. This lack is noticeable from the education of human resources to recruiting process in the Kosovar companies. This problem in noticed in preparing persons able to manage and direct the companies now and in the future. In Kosovo this is another weakness and only 2 years ago in one of the universities is opened a master program of Human Resources Management, the only of this kind in Kosova.

Exiting from the transition and gaining of a kind of independence in doing business has pressed some companies 
to invest in their human resources, by training them for different works within the company. Some other companies hesitate in doing this because of training costs.

According to Kumar (2014) training presents a prime opportunity to expand the knowledge base of all employees, but many employers find the development opportunities expensive. Employees also miss out on work time while attending training sessions, which may delay the completion of projects. Despite the potential drawbacks, training and development provides both the company as a whole and the individual employees with benefits that make the cost and time a worthwhile investment.

Is clearly seen that preparing of human resources is one of the principal factors for companies' development and especially when talking about the economies of in transition country as Kosova is. Preparing the right people for specific jobs is largely depended on their education.

The way of managing the people is important, especially when these people are facing with big changes as the transition is. According to Siengthai \& Bechter (2005) the changing management approach emphasizes productivity enhancement through methods that provide employees with both intrinsic and extrinsic rewards. Therefore, today, far from being marginalized, the HRM function becomes recognized as a central business concern. In practice, performance and delivery are integrated into line management for the aims shift from merely securing compliance to more ambitious ideals of winning commitment. Human resource investment has become one of the main business strategies of firms in creating their competitive advantage. These initiatives are associated with, and perhaps are even predicated upon, a tendency to shift from a collectivist orientation to an individualist workforce. Accordingly, management inspects for 'flexibility' and seeks to reward performance differentially.

According to Mrak (2000) human resources development, if countries in transition would like to increase international competitiveness of their companies, they will have to significantly strengthen their human resources capabilities. This implies that education and especially rehabilitation of R\&D capacities in the region will have to get much more prominent place in the next phase of transition.

Another problem encountered during this transition period in Kosova is the phenomenon "Brain gain". Many of Kosova youth have study abroad and only a small percentage of them are returning to give their contribute in economic development of the country.

Conditions as trade liberalization, growing emphasis on the knowledge economy, development of advanced ICT services, etc., has encouraged international labor mobility (Knight, 2005). One distinctive pattern of this mobility is the migration of skilled personnel from developing- to developed countries, often termed as 'brain drain'. The main concern, from a developmental perspective, on the outward flow of skilled people from the developing world arises from the negative consequences on growth and income levels back home.

According to Zenelaga and Sotirofski, (2011) in addition to the unaffordable loss of the considerable investment undertaken in generating these skills, already poor source countries lose their potentially most enterprising and ambitious young population, limiting future leadership and stifling the development of a more dynamic private sector.

\section{Conclusion}

There are numerous and still unresolved problems of transition in Kosova. In our case as in transition country is not difficult for companies to find the workforce because the work market, due to the high level of unemployment, is overflowed. What is difficult for Kosova businesses is to find employees that are able, skilled and have the qualities needed to perform the works. Since Kosova is country that with difficulties is exceeding the transition problems the companies must do maximum efforts to train and develop the human resources in way to be competitive in the market and to achieve their objectives.

The leaving of the youth from the country to study or other reasons presents a negative phenomenon for our country. The emigration of this important group as the talented and successful youth will have negative impact in economic and social development of the country. For this reason the government and the relevant institutions should take care in doing policies that will keep these precious resources within the country.

The reforms in education must be effective in way to prepare professional staff for the market needs. The companies' managers or leaders should take care in organizing trainings for their human resources in way to enhance the performance of the company and to succeed and be competitive in the market. 


\section{References}

A, Haslinda. (2009). Evolving terms of human resource management and development. The Journal of International Social Research. Volume $2 / 9$

Knight J. \& L. Song. (2005): Towards a Labour Market in China, Oxford. UK: Oxford University Press.

Kumar, Roopesh. (2014) Importance of training in organizational development. International Research Journal on Management Science and Technology, Volume 5, (Issue 1), 287

Mrak, Mojmir. (2000) Globalization: Trends, Callenges and Opportunities for countries in transition. United Nation - Industrial development organizations, pg.7

Pham Thio He, 2013, Human Resource Management in transitional economy in Vietnam

Siengthai, S. \& Bechter, C. (2005). Human Resource Management in Thailand: A Strategic Transition for Firm Competitiveness, Research and Practice in Human Resource Management, 13(1), 18-29.

Svetlik, I., Barisic, A., Kohont, A., Petkovic, M., Aleksic Miric, A., Slavic, A., ... Poor, J. (2010). Human Resource Management in the Countries of the Former Yugoslavia. Review of International Comparative Management, Volume 11(Issue 5), 808

Zenelaga Brunilda \& Kseanela Sotirofski, (2011), The 'Brain Gain Hypotheses`of Transition Countries Elites and Socioeconomic Development in Their Home Country. Almalaurea Working papers No.46 